\title{
Chryseobacterium caeni sp. nov., isolated from bioreactor sludge
}

\author{
Zhe-Xue Quan, ${ }^{1}$ Kwang Kyu Kim, ${ }^{2}$ Myung-Kyum Kim, ${ }^{2}$ Long $\mathrm{Jin}^{2}$ \\ and Sung-Taik Lee ${ }^{2}$ \\ ${ }^{1}$ Department of Microbiology and Microbial Engineering, School of Life Sciences, Fudan \\ University, Shanghai 200433, People's Republic of China \\ ${ }^{2}$ Department of Biological Sciences, Korea Advanced Institute of Science and Technology, \\ Daejeon 305-701, Republic of Korea
}

Correspondence

Sung-Taik Lee

e_stlee@kaist.ac.kr
The genus Chryseobacterium of the family Flavobacteriaceae was created by Vandamme et al. (1994) to accommodate six species formerly classified within the genus Flavobacterium. At present, the genus Chryseobacterium comprises 17 species: Chryseobacterium gleum (type species), C. balustinum, C. indologenes, C. indoltheticum and C. scophthalmum (Vandamme et al., 1994) and the recently described species C. defluvii (Kämpfer et al., 2003), C. joostei (Hugo et al., 2003), C. daecheongense (Kim et al., 2005a), C. formosense (Young et al., 2005), C. shigense (Shimomura et al., 2005), C. taichungense (Shen et al., 2005), C. vrystaatense (de Beer et al., 2005), C. hispanicum (Gallego et al., 2006), C. piscium (de Beer et al., 2006), C. soldanellicola (Park et al., 2006), C. taeanense (Park et al., 2006) and C. wanjuense (Weon et al., 2006). 'Chryseobacterium proteolyticum' was described by Yamaguchi \& Yokoe (2000), but this name has not yet been validly published. Two former Chryseobacterium species, $C$. meningosepticum (Vandamme et al., 1994) and C. miricola (Li et al., 2003), have been transferred to the novel genus Elizabethkingia (Kim et al., 2005b).

During a study of bacterial communities associated with the sludge of metal-complexed cyanide treatment bioreactors

The GenBank/EMBL/DDBJ accession number for the 16S rRNA gene sequence of strain $N 4^{\top}$ is DQ336714.

The API ZYM profiles of strain $N 4^{\top}$ and other Chryseobacterium species are available as supplementary material in IJSEM Online.
(Quan et al., 2006), conducted using a culture-dependent approach, a number of bacterial strains were isolated. Strain $\mathrm{N} 4^{\mathrm{T}}$ was isolated from a nickel-complexed cyanide treatment bioreactor. A comparative analysis of $16 \mathrm{~S}$ rRNA gene sequences indicated that strain $\mathrm{N} 4^{\mathrm{T}}$ was a member of the clade representing the genus Chryseobacterium. In order to determine the precise taxonomic position of strain $\mathrm{N} 4^{\mathrm{T}}$, a polyphasic taxonomic study was carried out.

Strain $\mathrm{N} 4^{\mathrm{T}}$ was cultivated on R2A agar (Difco) at $28^{\circ} \mathrm{C}$ for $48 \mathrm{~h}$. Cell biomass for quinone analysis and for DNA extraction was obtained directly from agar plates. For fatty acid methyl ester analysis, strain $\mathrm{N} 4^{\mathrm{T}}$ was cultivated on tryptic soy agar (Difco) at $28^{\circ} \mathrm{C}$ for $24 \mathrm{~h}$ for direct comparison with reference strains. Cell morphology was examined under a phase-contrast microscope $(1000 \times$ magnification; Nikon). A Gram reaction was performed as described by Gerhardt et al. (1994). Flexirubin-type pigments were detected according to the method of Fautz \& Reichenbach (1980). Catalase activity was determined by means of bubble production in a $3 \%(\mathrm{v} / \mathrm{v})$ hydrogen peroxide solution. Oxidase activity was determined from the oxidation of $1 \% p$-aminodimethylaniline oxalate. The hydrolysis of starch was tested on starch agar (Difco). Additional enzyme activities, acid production from carbohydrates and the utilization of various substrates as sole carbon sources were determined by using API ZYM, API 20E, API 20NE and API 32GN galleries according to the 
manufacturer's instructions (bioMérieux). The effects of $\mathrm{NaCl}$ concentration (0-5\%), $\mathrm{pH}(5-10)$ and temperature $\left(5-42{ }^{\circ} \mathrm{C}\right)$ on growth were determined on R2A agar.

Respiratory quinones were analysed as described by Komagata \& Suzuki (1987), using reversed-phase HPLC. For quantitative analysis of the cellular fatty acid composition, a loop of cell mass was harvested and the fatty acids were then saponified, methylated and extracted according to the protocol of the Sherlock Microbial Identification System (MIDI). Fatty acids were analysed by a gas chromatograph (model 6890; Hewlett Packard) and identified by using the Microbial Identification software package (Sasser, 1990). Chromosomal DNA was isolated and purified using a Cell Culture DNA Midi kit (Qiagen) according to the manufacturer's protocol. For the determination of $\mathrm{G}+\mathrm{C}$ content, DNA was degraded enzymically into nucleotides and analysed by reversed-phase HPLC as described by Mesbah et al. (1989). Non-methylated $\lambda$-phage DNA (Sigma) was used as a calibration reference.

The 16S rRNA gene was amplified by a PCR using two universal primers (Quan et al., 2005). The PCR product was purified using a QIAquick PCR purification kit (Qiagen). The 16S rRNA gene sequence was determined directly using the PCR-amplified DNA as a sequencing template. A sequencing PCR was performed with forward and reverse primers (Quan et al., 2005) using a DNA Analyzer (3730X1; Applied Biosystems). The 16S rRNA gene sequences of related taxa were obtained from GenBank. Multiple alignments were performed using the CLUSTAL_X program (Thompson et al., 1997) and gaps were edited in the BioEdit program (Hall, 1999). Phylogenetic trees were constructed on the basis of three tree-making algorithms: neighbour-joining (Saitou \& Nei, 1987), minimum-evolution (Rzhetsky \& Nei, 1992) and maximum-parsimony

Table 1. Phenotypic characteristics that differerentiate strain $\mathrm{N} 4^{\top}$ from other species of the genus Chryseobacterium

Taxa: 1, strain $\mathrm{N}^{\mathrm{T}}$ (data from this study); 2, C. gleum $(n=2) ; 3$, C. balustinum; 4, C. indologenes $(n=7)$; 5, C. indoltheticum; 6, C. scophthalmum ( $n=2)$; 7, C. defluvii (Kämpfer et al., 2003); 8, C. joostei ( $n=11)$; 9, C. daecheongense (Kim et al., 2005a); 10, C. formosense (Young et al., 2005); 11, C. taichungense (Shen et al., 2005); 12, C. shigense (Shimomura et al., 2005); 13, C. vrystaatense ( $n=36 ;$ de Beer et al., 2005); 14, C. soldanellicola (Park et al., 2006); 15, C. taeanense (Park et al., 2006); 16, C. piscium ( $n=4$; de Beer et al., 2006); 17, C. hispanicum (Gallego et al., 2006); 18, C. wanjuense (Weon et al., 2006). Data for taxa 2-6 and 8 are taken from Hugo et al. (2003). Number of strains examined, when greater than 1 , is shown in parentheses. +, Positive; W, weakly positive; -, negative; V, variable; D, delayed; NA, data not available.

\begin{tabular}{|c|c|c|c|c|c|c|c|c|c|c|c|c|c|c|c|c|c|c|}
\hline Characteristic & 1 & 2 & 3 & 4 & 5 & 6 & 7 & 8 & 9 & 10 & 11 & 12 & 13 & 14 & 15 & 16 & 17 & 18 \\
\hline \multicolumn{19}{|l|}{ Growth on/at: } \\
\hline MacConkey agar & - & + & + & + & + & - & - & + & - & - & - & - & - & - & - & - & - & $\mathrm{w}$ \\
\hline $5^{\circ} \mathrm{C}$ & + & - & $\mathrm{D}$ & - & + & $\mathrm{D}$ & - & + & - & - & - & + & + & + & + & + & $\mathrm{D}$ & + \\
\hline $37^{\circ} \mathrm{C}$ & + & + & + & - & - & - & + & - & + & - & + & - & - & + & + & - & - & + \\
\hline $42^{\circ} \mathrm{C}$ & - & - & - & - & - & - & + & - & - & - & - & - & - & - & - & - & - & - \\
\hline Urease activity & + & - & - & - & - & + & - & $\mathrm{V}$ & - & - & - & - & + & - & - & + & - & - \\
\hline Nitrate reduction & - & + & + & - & - & - & - & - & + & - & - & - & - & - & - & + & + & - \\
\hline Nitrite reduction & - & + & - & - & - & - & + & - & - & NA & $\mathrm{NA}$ & - & + & - & - & - & + & NA \\
\hline \multicolumn{19}{|l|}{ Hydrolysis of: } \\
\hline Tween 80 & - & + & + & + & + & + & NA & + & NA & - & NA & NA & + & - & + & $\mathrm{V}$ & - & NA \\
\hline Starch & - & + & - & + & - & - & + & + & + & NA & NA & + & - & NA & NA & - & + & + \\
\hline \multicolumn{19}{|l|}{ Production of: } \\
\hline Hydrogen sulphide & - & - & - & - & + & - & - & - & - & - & - & + & $\mathrm{V}$ & - & - & - & - & NA \\
\hline Indole & - & + & + & + & + & - & + & + & - & + & $\mathrm{W}$ & + & + & - & - & + & $\mathrm{W}$ & - \\
\hline \multicolumn{19}{|l|}{ Acid production from: } \\
\hline L-Arabinose & - & + & - & - & - & - & - & - & - & - & - & - & NA & - & - & NA & + & - \\
\hline D-Fructose & - & + & + & $\mathrm{D}$ & - & - & + & + & + & NA & NA & + & NA & - & - & NA & + & - \\
\hline Glycerol & - & + & - & $\mathrm{D}$ & - & - & + & $\mathrm{V}$ & + & NA & NA & - & NA & - & - & NA & + & - \\
\hline Lactose & - & - & - & - & - & - & - & - & - & NA & - & - & NA & - & - & NA & - & - \\
\hline D-Maltose & - & + & - & + & + & - & + & + & + & - & + & - & NA & - & - & NA & + & - \\
\hline D-Mannitol & - & - & - & - & - & - & - & $\mathrm{V}$ & - & - & - & - & NA & - & - & NA & - & - \\
\hline Trehalose & - & + & - & + & - & + & + & + & + & + & + & - & NA & - & - & NA & - & + \\
\hline D-Xylose & - & + & - & - & - & - & - & - & - & $\mathrm{w}$ & + & - & $\mathrm{NA}$ & - & - & $\mathrm{NA}$ & + & - \\
\hline DNA G $+\mathrm{C}$ content $(\mathrm{mol} \%)^{*}$ & 38.2 & 38.0 & 33.1 & 38.5 & 33.8 & 34.2 & 38.8 & 36.8 & 36.6 & NA & NA & 36.6 & 37.1 & 28.8 & 32.1 & 33.6 & 34.3 & 37.8 \\
\hline
\end{tabular}

${ }^{\star}$ DNA G $+\mathrm{C}$ contents shown are for type strains. 
Table 2. Cellular fatty acid profiles (\%) of strain $N 4^{\top}$ and species of the genus Chryseobacterium

Taxa: 1, strain N4 ${ }^{\mathrm{T}}$; 2, C. gleum ( $n=5$; data from Hugo et al., 1999); 3, C. balustinum; 4, C. indologenes ( $n=45$; Hugo et al., 1999); 5, C. indoltheticum; 6, C. scophthalmum ( $n=7)$; 7, C. defluvii (Kämpfer et al., 2003); 8, C. joostei ( $n=11$; Hugo et al., 2003); 9, C. daecheongense (Kim et al., 2005a); 10, C. formosense (Young et al., 2005); 11, C. taichungense (Shen et al., 2005); 12, C. shigense (A. Hiraishi, personal communication); 13, C. vrystaatense ( $n=7$; de Beer et al., 2005); 14, C. soldanellicola (Park et al., 2006); 15, C. taeanense (Park et al., 2006); 16, C. piscium ( $n=4$; de Beer et al., 2006); 17, C. hispanicum (Gallego et al., 2006); 18, C. wanjuense (Weon et al., 2006). Data for taxa 3, 5 and 6 are taken from Mudarris et al., 1994. Number of strains examined, when greater than 1, is shown in parentheses. For all strains studied, fatty acids that account for $<1 \%$ of the total fatty acid content are not shown so the percentages do not add up to $100 \%$. Means \pm SD are given. tr, Trace $(<1 \%)$; ND, not detected; ECL, equivalent chain-length (i.e. the identity of the fatty acid is unknown).

\begin{tabular}{|c|c|c|c|c|c|c|c|c|c|c|c|c|c|c|c|c|c|c|}
\hline Fatty acid & 1 & 2 & 3 & 4 & 5 & 6 & 7 & 8 & 9 & 10 & 11 & 12 & 13 & 14 & 15 & 16 & 17 & 18 \\
\hline $\begin{array}{l}\text { Unknown, } \\
\text { ECL } 13.566\end{array}$ & 2.6 & $1.2 \pm 0.4$ & 1.6 & $2.1 \pm 0.7$ & $\operatorname{tr}$ & $3.3 \pm 0.5$ & $\operatorname{tr}$ & $1.1 \pm 0.2$ & 1.5 & $\operatorname{tr}$ & 6.7 & 2.4 & $1.4 \pm 0.3$ & 2.3 & 3.1 & $\operatorname{tr}$ & 1.0 & 2.9 \\
\hline iso- $\mathrm{C}_{15: 0} 3-\mathrm{OH}$ & 3.2 & $2.5 \pm 0.1$ & 2.7 & $2.6 \pm 0.2$ & 2.2 & $2.9 \pm 0.1$ & 2.6 & $2.9 \pm 0.3$ & 2.0 & 1.8 & 4.3 & 4.1 & $2.7 \pm 0.3$ & 2.7 & 3.1 & $2.4 \pm 0.3$ & 4.0 & 3.7 \\
\hline anteiso- $\mathrm{C}_{15: 0}$ & 4.3 & $\overline{\operatorname{tr}}$ & $\operatorname{tr}$ & $\overline{\operatorname{tr}}$ & 4.9 & $\overline{\operatorname{tr}}$ & 3.2 & $\overline{\operatorname{tr}}$ & 1.0 & 2.1 & $\operatorname{tr}$ & $\operatorname{tr}$ & $1.7 \pm 0.7$ & 1.9 & 1.1 & $2.7 \pm 1.9$ & 3.6 & $\operatorname{tr}$ \\
\hline$C_{16: 0}$ & 13.5 & $1.3 \pm 0.4$ & 1.6 & $\operatorname{tr}$ & $\operatorname{tr}$ & $1.1 \pm 0.1$ & 1.3 & $\operatorname{tr}$ & 1.8 & 1.5 & 1.3 & $\operatorname{tr}$ & $1.1 \pm 0.4$ & 1.4 & 1.8 & $1.1 \pm 0.2$ & 2.4 & $\operatorname{tr}$ \\
\hline $\mathrm{C}_{16: 0} 3-\mathrm{OH}$ & 6.7 & $1.1 \pm 0.1$ & 1.4 & $1.0 \pm 0.2$ & $\operatorname{tr}$ & $1.3 \pm 0.1$ & $\operatorname{tr}$ & $1.2 \pm 0.2$ & $\operatorname{tr}$ & $\operatorname{tr}$ & 2.6 & 1.3 & $1.3 \pm 0.3$ & 1.3 & $\operatorname{tr}$ & $1.3 \pm 0.3$ & 4.4 & $\mathrm{ND}$ \\
\hline iso- $\mathrm{C}_{17: 0}$ & ND & $1.6 \pm 0.6$ & 1.0 & $\operatorname{tr}$ & $\operatorname{tr}$ & $1.1 \pm 0.1$ & 2.0 & $\operatorname{tr}$ & 3.0 & 2.3 & $\operatorname{tr}$ & $\operatorname{tr}$ & $\operatorname{tr}$ & $\operatorname{tr}$ & 1.1 & $1.2 \pm 0.2$ & ND & 2.9 \\
\hline iso- $\mathrm{C}_{17: 0} 3-\mathrm{OH}$ & 9.8 & $21.8 \pm 0.3$ & 16.8 & $19.2 \pm 1.8$ & 15.4 & $17.1 \pm 0.2$ & 14.1 & $20.1 \pm 1.2$ & 15.7 & 10.9 & 22.4 & 19.6 & $15.4 \pm 1.8$ & 17.7 & 18.8 & $16.2 \pm 3.1$ & 17.6 & 21.9 \\
\hline iso- $\mathrm{C}_{17: 1} \omega 9 c$ & ND & $20.2 \pm 3.9$ & 27.1 & $24.2 \pm 3.1$ & 24.6 & $21.3 \pm 0.4$ & 3.8 & $22.9 \pm 1.9$ & 7.6 & 4.3 & 8.9 & 11.9 & $19.7 \pm 2.3$ & 14.6 & 15.8 & $18.7 \pm 2.8$ & 1.3 & 11.7 \\
\hline $\begin{array}{l}\text { Summed } \\
\text { feature } 4^{*}\end{array}$ & 32.4 & $11.8 \pm 0.8$ & 9.2 & $11.1 \pm 1.3$ & 12.0 & $11.8 \pm 0.6$ & 6.5 & $12.1 \pm 1.3$ & 8.4 & 6.5 & 13.8 & 12.4 & $9.1 \pm 0.9$ & 9.7 & 11.2 & $10.8 \pm 1.3$ & 26.7 & 11.0 \\
\hline
\end{tabular}

${ }^{\star}$ Summed feature 4 contains iso- $\mathrm{C}_{15: 0} 2-\mathrm{OH}$ and/or $\mathrm{C}_{16: 1} \omega 7 c / t$.

(Swofford, 1993) by using the MEGA3 program (Kumar et al., 2004), with bootstrap values based on 1000 replications (Felsenstein, 1985). Evolutionary distances were calculated using the method of Jukes \& Cantor (1969).

Details of the cultural, physiological and biochemical characteristics of strain $\mathrm{N} 4^{\mathrm{T}}$ are given in the species description and in Table 1. The results from the API ZYM galleries are available in Supplementary Table S1 in IJSEM Online. The cellular fatty acid profile of strain $N 4^{\mathrm{T}}$ was characterized by the predominance of summed feature 4 (iso- $\mathrm{C}_{15: 0} 2-\mathrm{OH}$ and/or $\mathrm{C}_{16: 1} \omega 7 c / t$ ), iso- $\mathrm{C}_{15: 0}$ and $\mathrm{C}_{16: 0}$, and was similar to those of other Chryseobacterium species. However, $\mathrm{N} 4^{\mathrm{T}}$ differed from other Chryseobacterium species (except $C$. hispanicum) in containing a very large amount of summed feature 4 and lacking iso- $\mathrm{C}_{17: 1} \omega 9 c$ (Table 2). The predominant respiratory quinone was menaquinone MK-6. The DNA G + C content was $38.2 \mathrm{~mol} \%$.

The almost-complete 16S rRNA gene sequence (1483 bp) of strain $\mathrm{N}^{\mathrm{T}}$ was determined. The levels of $16 \mathrm{~S}$ rRNA gene sequence similarity between $\mathrm{N} 4^{\mathrm{T}}$ and the type strains of other Chryseobacterium species ranged from $95.8 \%$ (with C. joostei) to $93.2 \%$ (with C. balustinum). Sequence similarities with all other species of the family Flavobacteriaceae included in the phylogenetic analysis were below $93.4 \%$. In the phylogenetic tree based on the neighbour-joining algorithm, strain $\mathrm{N} 4^{\mathrm{T}}$ clustered with species of the genus Chryseobacterium (Fig. 1). Similar tree topologies were also found in the trees generated with the maximum-parsimony and minimum-evolution algorithms (data not shown).

The above-mentioned chemotaxonomic features, together with the morphological, physiological and biochemical characteristics, strongly support the classification of strain $\mathrm{N}^{\mathrm{T}}$ within the genus Chryseobacterium. The phylogenetic distinctiveness was sufficient to categorize strain $\mathrm{N} 4^{\mathrm{T}}$ as representing a novel species within the genus Chryseobacterium (Stackebrandt \& Goebel, 1994). The strain could also be distinguished from other Chryseobacterium species by means of some important phenotypic characteristics (summarized in Table 1): growth conditions, enzyme activities, acid production from carbohydrates, fatty acid profile (Table 2) and API ZYM profile (see Supplementary Table S1 in IJSEM Online). On the basis of the results obtained, strain $\mathrm{N} 4^{\mathrm{T}}$ is sufficiently distinct from all known Chryseobacterium species to be recognized as representing a novel species of the genus Chryseobacterium, for which the name Chryseobacterium caeni sp. nov. is proposed.

\section{Description of Chryseobacterium caeni sp. nov.}

Chryseobacterium caeni (ca.e' ni. L. gen. n. caeni of sludge).

Cells are aerobic, non-spore-forming, non-motile rods. Gram-negative, oxidase- and catalase-positive. Good growth is observed on R2A, tryptic soy and nutrient agars, but not on MacConkey agar. Colonies are translucent and shiny with entire edges, becoming mucoid after 3 days 


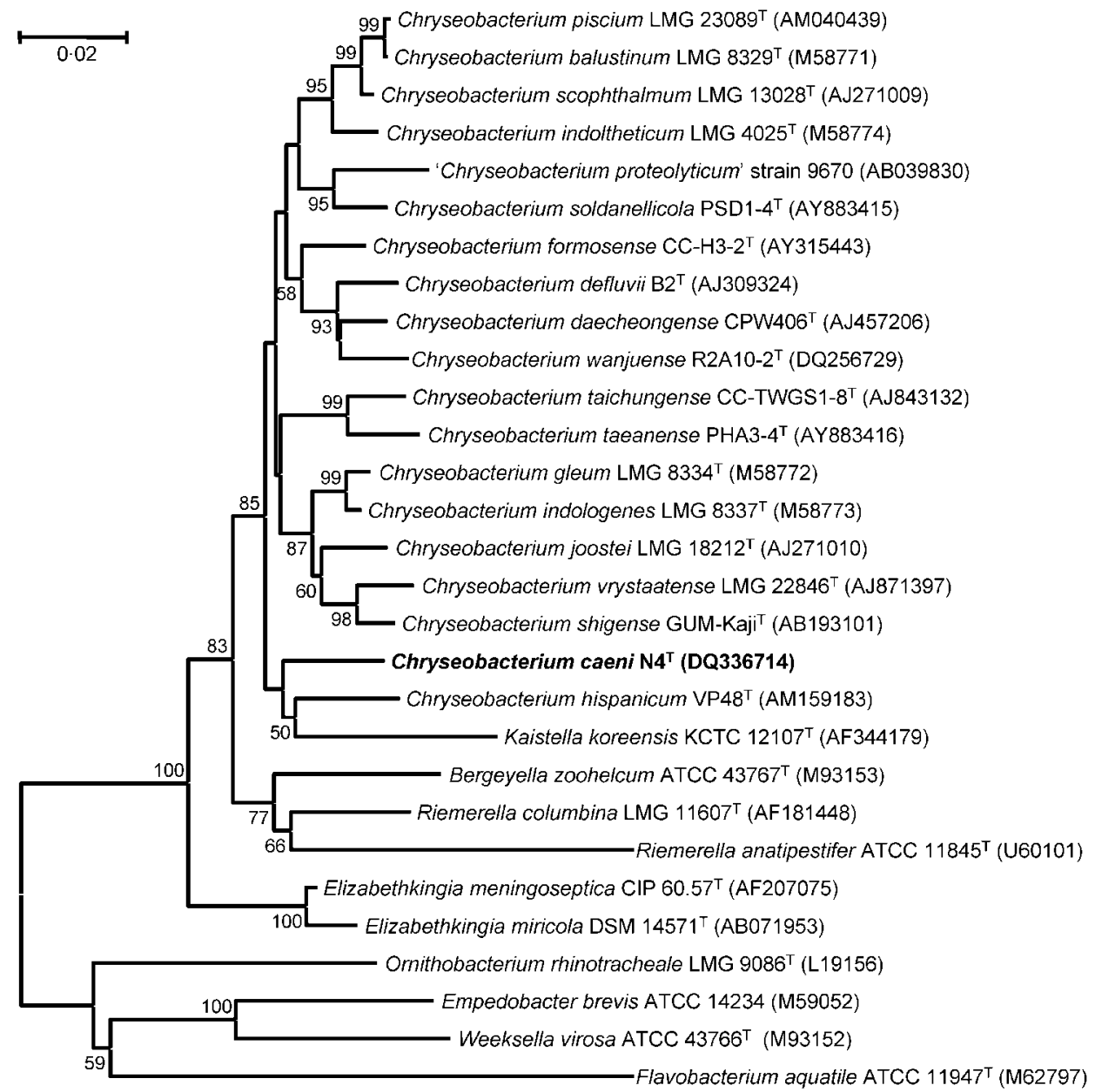

Fig. 1. Neighbour-joining tree showing the phylogenetic positions of Chryseobacterium caeni $\mathrm{N} 4^{\top}$ and nearest neighbours based on 16S rRNA gene sequences. Species of some genera within the family Flavobacteriaceae were used to define the root. Bootstrap values (expressed as percentages of 1000 replications) greater than $50 \%$ are shown at the branching points. Bar, 2 substitutions per 100 nucleotide positions.

incubation. Bright yellow flexirubin-type pigments are produced. Growth occurs at $5-37^{\circ} \mathrm{C}$, but not at $42^{\circ} \mathrm{C}$; the optimum temperature for growth is between 28 and $30^{\circ} \mathrm{C}$. The $\mathrm{pH}$ range for growth is $6.0-10.0$, with an optimum at between $\mathrm{pH} 6.5$ and 8.0. Cells grow in the presence of $0-3 \%$ $\mathrm{NaCl}$, but not with $5 \% \mathrm{NaCl}$. The major fatty acids are summed feature 4 (iso- $\mathrm{C}_{15: 0} 2-\mathrm{OH}$ and/or $\mathrm{C}_{16: 1} \omega 7 \mathrm{ct} t$ ), iso$\mathrm{C}_{15: 0}$ and $\mathrm{C}_{16: 0}$. Menaquinone MK-6 is the predominant respiratory quinone. The $\mathrm{G}+\mathrm{C}$ content of the genomic DNA is $38.2 \mathrm{~mol} \%$. Acid is not produced from amygdalin, $\mathrm{L}-$ arabinose, D-fructose, D-glucose, glycerol, inositol, lactose, D-melibiose, D-maltose, D-mannitol, L-rhamnose, D-sorbitol, D-sucrose, trehalose or D-xylose. The following substrates are utilized as sole carbon sources: D-glucose, L-arabinose, Dsucrose, D-maltose and glycogen. The following substrates are not utilized as sole carbon sources: D-mannitol, Dmelibiose, L-fucose, D-sorbitol, propionate, caprate, valerate, citrate, histidine, 2-ketogluconate, 3-hydroxybutyrate, 4-hydroxybenzoate, L-proline, L-rhamnose, $\mathrm{N}$-acetylglucosamine, D-ribose, inositol, itaconate, suberate, malonate, acetate, DL-lactate, L-alanine, 5-ketogluconate, 3-hydroxybenzoate, L-serine, D-mannose, gluconate, caprate, adipate, malate or phenyl acetate. Positive for urease and $\beta$-glucosidase activities, but negative for indole production. Nitrate and nitrite are not reduced. Results from the API ZYM test are given in Supplementary Table S1 in IJSEM Online.

The type strain, $\quad \mathrm{N} 4^{\mathrm{T}} \quad\left(=\mathrm{KCTC} \quad 12506^{\mathrm{T}}=\mathrm{CCBAU}\right.$ $10201^{\mathrm{T}}=$ DSM $17710^{\mathrm{T}}$ ), was isolated from the sludge of a nickel-complexed cyanide treatment bioreactor.

\section{Acknowledgements}

This work was supported by the 21C Frontier Microbial Genomics and Application Center Program, Ministry of Science and Technology (grant MG05-0101-4-0), Republic of Korea. 


\section{References}

de Beer, H., Hugo, C. J., Jooste, P. J., Willems, A., Vancanneyt, M., Coenye, T. \& Vandamme, P. (2005). Chryseobacterium vrystaatense sp. nov., isolated from raw chicken in a chicken-processing plant. Int J Syst Evol Microbiol 55, 2149-2153.

de Beer, H., Hugo, C. J., Jooste, P. J., Vancanneyt, M., Coenye, T. \& Vandamme, P. (2006). Chryseobacterium piscium sp. nov., isolated from fish of the South Atlantic Ocean off South Africa. Int J Syst Evol Microbiol 56, 1317-1322.

Fautz, E. \& Reichenbach, H. (1980). A simple test for flexirubin-type pigments. FEMS Microbiol Lett 8, 87-91.

Felsenstein, J. (1985). Confidence limit on phylogenies: an approach using the bootstrap. Evolution 39, 783-791.

Gallego, V., García, M. T. \& Ventosa, A. (2006). Chryseobacterium hispanicum sp. nov., isolated from the drinking water distribution system of Sevilla, Spain. Int J Syst Evol Microbiol 56, 1589-1592.

Gerhardt, P., Murray, R. G. E., Wood, W. A. \& Krieg, N. R. (editors) (1994). Methods for General and Molecular Bacteriology. Washington, DC: American Society for Microbiology.

Hall, T. A. (1999). BioEdit: a user-friendly biological sequence alignment editor and analysis program for Windows 95/98/NT. Nucleic Acids Symp Ser 41, 95-98.

Hugo, C. J., Jooste, P. J., Segers, P., Vancanneyt, M. \& Kersters, L. (1999). A polyphasic taxonomic study of Chryseobacterium strains isolated from dairy sources. Syst Appl Microbiol 22, 586-595.

Hugo, C., Segers, P., Hoste, B., Vancanneyt, M. \& Kersters, K. (2003). Chryseobacterium joostei sp. nov., isolated from the dairy environment. Int J Syst Evol Microbiol 53, 771-777.

Jukes, T. H. \& Cantor, C. R. (1969). Evolution of protein molecules. In Mammalian Protein Metabolism, vol. 3, pp. 21-132. Edited by H. N. Munro. New York: Academic Press.

Kämpfer, P., Dreyer, U., Neef, A., Dott, W. \& Busse, H. J. (2003). Chryseobacterium defluvii sp. nov., isolated from wastewater. Int J Syst Evol Microbiol 53, 93-97.

Kim, K. K., Bae, H. S., Schumann, P. \& Lee, S. T. (2005a). Chryseobacterium daecheongense sp. nov., isolated from freshwater lake sediment. Int J Syst Evol Microbiol 55, 133-138.

Kim, K. K., Kim, M. K., Lim, J. H., Park, H. Y. \& Lee, S. T. (2005b). Transfer of Chryseobacterium meningosepticum and Chryseobacterium miricola to Elizabethkingia gen. nov. as Elizabethkingia meningoseptica comb. nov. and Elizabethkingia miricola comb. nov. Int J Syst Evol Microbiol 55, 1287-1293.

Komagata, K. \& Suzuki, K. I. (1987). Lipids and cell-wall analysis in bacterial systematics. Methods Microbiol 19, 161-203.

Kumar, S., Tamura, K. \& Nei, M. (2004). MEGA3: integrated software for molecular evolutionary genetics analysis and sequence alignment. Brief Bioinform 5, 150-163.

Li, Y., Kawamura, K., Fujiwara, N., Naka, T., Liu, H., Huang, X., Kobayashi, K. \& Ezaki, T. (2003). Chryseobacterium miricola sp. nov., a novel species isolated from condensation water of space station Mir. Syst Appl Microbiol 26, 523-528.
Mesbah, M., Premachandran, U. \& Whitman, W. B. (1989). Precise measurement of the $\mathrm{G}+\mathrm{C}$ content of deoxyribonucleic acid by highperformance liquid chromatography. Int J Syst Bacteriol 39, 159-167.

Mudarris, M., Austin, B., Segers, P., Vancanneyt, M., Hoste, B. \& Bernardet, J. F. (1994). Flavobacterium scophthalmum sp. nov., a pathogen of turbot (Scophthalmus maximus L.). Int J Syst Bacteriol 44, 447-453.

Quan, Z. X., Bae, H. S., Baek, J. H., Chen, W. F., Im, W. T. \& Lee, S. T. (2005). Rhizobium daejeonense sp. nov. isolated from a cyanide treatment bioreactor. Int J Syst Evol Microbiol 55, 2543-2549.

Quan, Z. X., Rhee, S. K., Bae, J. W., Baek, J. H., Park, Y. H. \& Lee, S. T. (2006). Bacterial community structure in activated sludge reactors treating free or metal-complexed cyanides. J Microbiol Biotechnol 16, 232-249.

Rzhetsky, A. \& Nei, M. (1992). A simple method for estimating and testing minimum-evolution trees. Mol Biol Evol 9, 945-967.

Saitou, N. \& Nei, M. (1987). The neighbour-joining method: a new method for reconstructing phylogenetic trees. Mol Biol Evol 4, 406-425.

Sasser, M. (1990). Identification of Bacteria by Gas Chromatography of Cellular Fatty Acids, MIDI Technical Note 101. Newark, DE: MIDI.

Shen, F. O., Kämpfer, P., Young, C. C., Lai, W. A. \& Arun, A. B. (2005). Chryseobacterium taichungense sp. nov., isolated from contaminated soil. Int J Syst Evol Microbiol 55, 1301-1304.

Shimomura, K., Kaji, S. \& Hiraishi, A. (2005). Chryseobacterium shigense sp. nov., a yellow-pigmented aerobic bacterium isolated from a lactic acid beverage. Int J Syst Evol Microbiol 55, 1903-1906.

Stackebrandt, E. \& Goebel, B. M. (1994). Taxonomic note: a place for DNA-DNA reassociation and 16S rDNA sequence analysis in the present species identification in bacteriology. Int J Syst Bacteriol 44, 846-849.

Swofford, D. L. (1993). PAUP. Phylogenetic Analysis Using Parsimony, version 3.1.1. Champaign, IL: Illinois Natural History Survey.

Thompson, J. D., Gibson, T. J., Plewniak, F., Jeanmougin, F. \& Higgins, D. G. (1997). The CLUSTAL_X windows interface: flexible strategies for multiple sequence alignment aided by quality analysis tools. Nucleic Acids Res 25, 4876-4882.

Vandamme, P., Bernardet, J. F., Segers, P., Kersters, K. \& Holmes, B. (1994). New perspectives in the classification of the flavobacteria: description of Chryseobacterium gen. nov., Bergeyella gen. nov., and Empedobacter nom. rev. Int J Syst Bacteriol 44, 827-831.

Weon, H. Y., Kim, B. Y., Yoo, S. H., Kwon, S. W., Cho, Y. H., Go, S. J. \& Stackebrandt, E. (2006). Chryseobacterium wanjuense sp. nov., isolated from greenhouse soil in Korea. Int J Syst Evol Microbiol 56, 1501-1504.

Yamaguchi, S. \& Yokoe, M. (2000). A novel protein-deamidating enzyme from Chryseobacterium proteolyticum sp. nov., a newly isolated bacterium from soil. Appl Environ Microbiol 66, 3337-3343.

Young, C. C., Kämpfer, P., Shen, E. T., Lai, W. A. \& Arun, A. B. (2005). Chryseobacterium formosense sp. nov., isolated from the rhizosphere of Lactuca sativa L. (garden lettuce). Int J Syst Evol Microbiol 55, 423-426. 